\title{
Microscopy of Polymer Composites
}

\author{
Jan Hajsman \& Stepan Jenicek
}
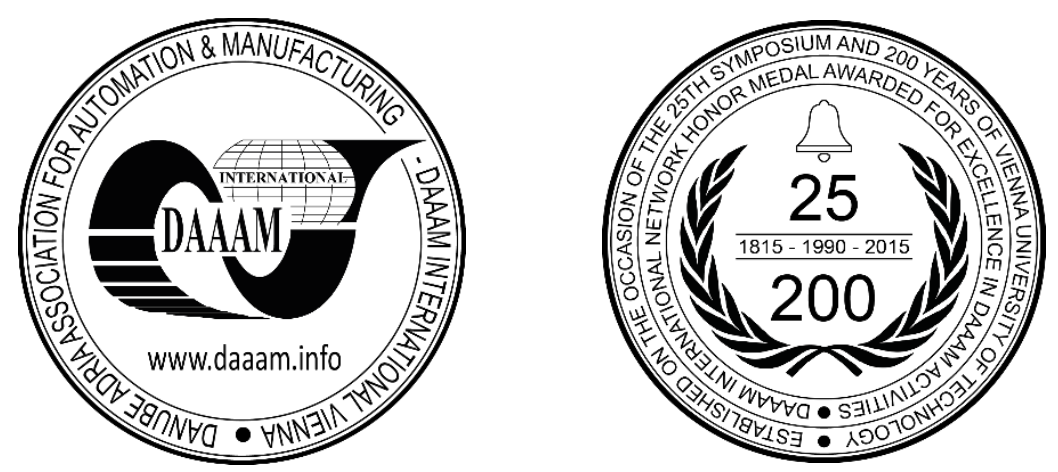

This Publication has to be referred as: Hajsman, J[an] \& Jenicek, S[tepan] (2018). Microscopy of Polymer Composites, Proceedings of the 29th DAAAM International Symposium, pp.1293-1298, B. Katalinic (Ed.), Published by DAAAM International, ISBN 978-3-902734-20-4, ISSN 1726-9679, Vienna, Austria DOI: $10.2507 / 29$ th.daaam.proceedings.186

\begin{abstract}
This work aims to optimize the methods of light and electron microscopy for documentation of polymer composite samples. The main task was to adapt the well-known techniques of metallography (i.e. sample preparation and microscopic examination) to multi-component polymer materials. There were several problems to deal with (e.g. low melting point, absence of electrical conductivity) which make the process different from metal samples preparation and investigation. The experiment consisted of finding a suitable mounting resin for the sample then optimising the process of grinding and polishing and finally documenting the microstructure using light and scanning electron microscopy (SEM). Samples in the undeformed state were examined as well as the samples subjected to tensile test at different temperatures.
\end{abstract}

Keywords: polymer composites; microscopy; metallography; scanning electron microscopy; light microscopy

\section{Introduction}

Composite material consists at least of two components or phases which are combined in a specific way to reach unique mechanical, physical and chemical properties. There are two main types of components: matrix and the reinforcing phase. In case of the polymer composites both of the main components are made of polymer material (i.e. organic compound). The Matrix defines the shape of the product, absorbs the impact and protects the reinforcing phase. It is made either of thermoplastic or thermoset polymers. The most used thermosets are for example epoxies, unsaturated polyesters, melamine or phenol-formaldehyde resins [1]. They are usually supplied in the liquid form and they cure by a chemical reaction during the manufacturing. The liquid form makes them easier to process as they perfectly fill all the space between the reinforcing phase elements. On the other hand thermoplastic materials have to be melted for the purposes of processing. High viscosity of thermoplastics makes the manufacturing more energyintensive. Some of the most common thermoplastics in the composite manufacturing are polyetheretherketon (PEEK), polyphenylsulfide (PPS), polyamide-imides (PAI), polyimides (PI) and polysulfones (PSUL) [2].

The reinforcing phase is usually constituted by particles or fibers. The synthetic fibers are well known by their commercial names such as Kevlar (aramid fiber), Spectra (polyethylen), Vectran (polyester) or Zylon (poly(p-fenylenbenzobisoxazol)) [2], [3]. To reinforce polymer matrices, only plant fibers based on cellulose are suitable for all natural fibers. These include cannabis, sisal, jute, ramie and cotton. Composites with natural fibers are often used where there is no strong need for strength and their function is more aesthetic [4]. 
In addition to the properties of the matrix and the secondary phase, the properties of the composite are significantly influenced by the physical and chemical nature of the phase interface between the matrix and the dispersed phase. The nature of the phase interface affects the coherence between the reinforcement and the matrix, and hence the mechanical properties of the composite. There are a number of chemical compounds and technological processes to achieve the desired adhesive strength between the reinforcement and the matrix [5].

Polymer composites are a group of materials whose importance and range of utilization is growing steadily. In applications where the operating conditions allow it, composites replace conventional materials. Their advantages are above all low weight, greater shape variability, good strength properties, chemical resistance, etc. [6]. With the increase in production volume and the number of new types of polymer composites, grows also the necessity of developing suitable testing procedures. This study focuses specifically on light microscopy and scanning electron microscopy of multicomponent polymer materials. The main purpose of the experiment was to learn how to use the equipment of metallographic laboratory of Regional Institute of Technology WBU in Pilsen in polymer composite research. The standard procedures commonly used in metallography (i.e. sample cutting, mounting, grinding, polishing and imaging) had to be modified to fit the needs of this kind of material. The aim was to test the feasibility and to find possible limitations of microscopic imaging of polymer composite rather than to bring some specific results.

This experiment was related to research of moulding processes of polymer composites which is also a possible field of application of the methods tested in this study.

\section{Polymer composite sample preparation}

The material employed for this study is a composite consisting of a flexible plastic sheet of around $1 \mathrm{~mm}$ thickness and nonwoven fabric which covers one side of the sheet. It is an intermediate product designed to speed up and facilitate the moulding procedures in automotive industry. Based on the results of thermogravimetric analysis, differential scanning calorimetry and infrared spectroscopy the sheet was identified as ethylene-propylene copolymer and the nonwoven fabric as polyethylene terephthalate (PET).

The first step was to observe the microstructure using the light microscopy. For this purpose samples $10 \times 10 \mathrm{~mm}$ were cut. Since the melting point of the sheet is quite low $\left(160{ }^{\circ} \mathrm{C}\right)$, there is a need to use cold mounting resin for the sample preparation, which makes the process more time-consuming. Two mounting resins were tested: acrylic resin and epoxy resin. The observations were carried out in a plane perpendicular to the sheet surface, where both the matrix and the fibers are clearly visible. Results obtained using acrylic resins (Fig. 1.a) were considered unacceptable as the contrast between the resin and the sample is low. The acrylic resin contains tiny cavities which may be confused with the fibers. On the other hand epoxy resin (Fig. 1.b) seems to be a suitable fixing material in which all the components are easily recognizable. Due to its low viscosity in the initial state epoxy resin fills all the cracks in the surface as well as the space between the protruding fibers.

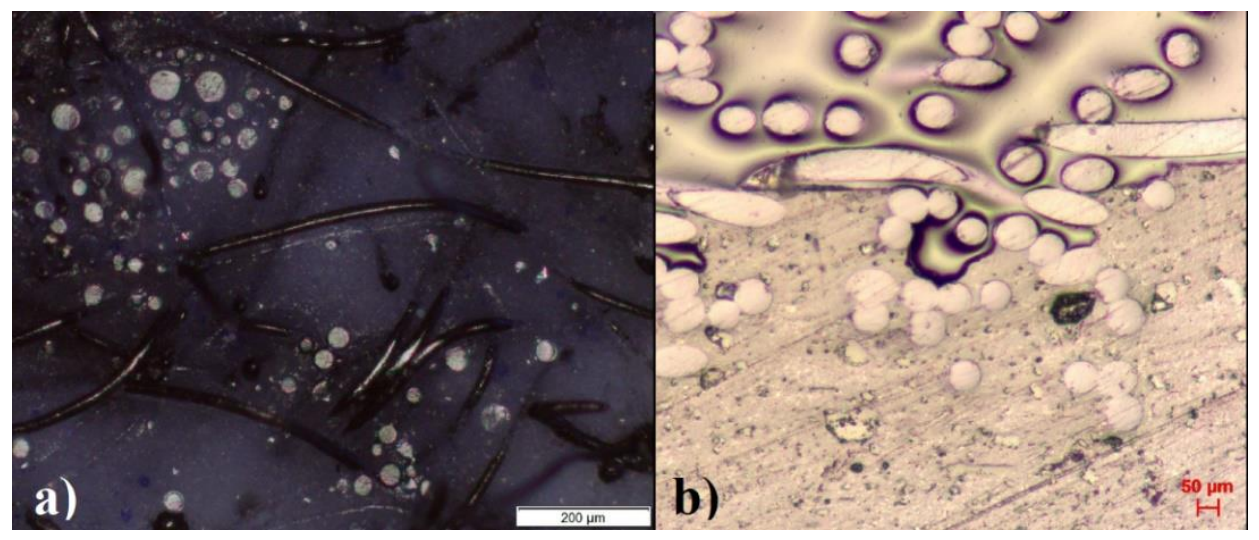

Fig. 1. Comparison of mounting resins: a) acrylic resin, b) epoxy resin

The process of sample grinding was optimized to get the clearest image possible. Polishing was not beneficial to the final result thus the whole procedure consists only of grinding using diamond discs (Table 1).

\begin{tabular}{|c|c|c|c|c|c|}
\hline \multirow{2}{*}{ Disc Type } & \multirow{2}{*}{ Granularity } & \multirow{2}{*}{ Time [min] } & \multirow{2}{*}{ Force [N] } & \multicolumn{2}{|c|}{ RPM } \\
\cline { 2 - 4 } & & & Disc & Grinding Head \\
\hline \multirow{3}{*}{ Struers MD Piano } & 80 & 1 & 30 & & \\
\cline { 2 - 4 } & 220 & 1 & 25 & \multirow{3}{*}{300} & 120 \\
\cline { 2 - 4 } & 500 & 1 & 25 & & \\
\cline { 2 - 4 } & 1200 & individually & 25 & & \\
\hline
\end{tabular}

Table 1. Sample grinding procedure 
In the same manner the samples of deformed tensile specimens were prepared. The tensile tests were carried out at temperatures $20,40,60,80,100,120,140$ and $160{ }^{\circ} \mathrm{C}$. The saples were cut close to the fracture surface. At elevated temperatures $\left(80^{\circ} \mathrm{C}\right.$ and more) the ductility of the material increased strongly and the fracture didn't appear any more. Then the samples were taken from the middle of the deformed part to observe the deformation behaviour temperature dependence

\section{Microscopic observation optimization}

While there is no significant difficulty in observing polymer samples through a light microscope, electron microscopy brings several problems. Conventional scanning electron microscopy provides a good image only for electrically conductive samples. In the case of non-conducting samples, the accumulation of the negative charge occurs at the points of impact of the electron beam, resulting in deterioration in the quality of the resulting image. In order to suppress this phenomenon, the surface of samples is usually coated with a conductive layer, (i. e. metal or carbon thin film). If the sample surface is very rough, it is difficult to create a perfectly consistent layer that covers all the area and ensures conducting of the charge away from the sample. Applying such a layer can hide some fine details of the original surface, since the electron beam scans only this layer and not the sample itself. If the chemical composition is to be investigated, the feasibility of the measurement will depend on the primary electron beam energy and on the thickness of the conductive layer [7], [8].

Another possibility to observe non-conductive preparations by scanning electron microscopy is using a low vacuum in the specimen chamber $\left(10^{-1}-10^{2} \mathrm{~Pa}\right)$, while the optical system is separated from the chamber by vacuum membrane. At this pressure the atmosphere around the specimen becomes highly conductive due to electron ionization. In this way, the charge generated on the surface of the sample is compensated by the surrounding atmosphere ions. Other methods of observing non-conductive specimens include a surface discharging with ion beam, an overlapping sample with a metal foil with a small aperture, X-ray irradiation, or the use of low energy electron beam. The disadvantage of examining polymers by electron microscopy is the fact that these materials may be susceptible to damage by the electron beam [7].

In present study acceptable results were obtained using low vacuum in the specimen chamber. The pressure was set to $30 \mathrm{~Pa}$. This is probably the easiest and the most economic method, since no expensive and time-consuming coating process is needed. Various types of SEM imagining were tested (Fig. 2.).
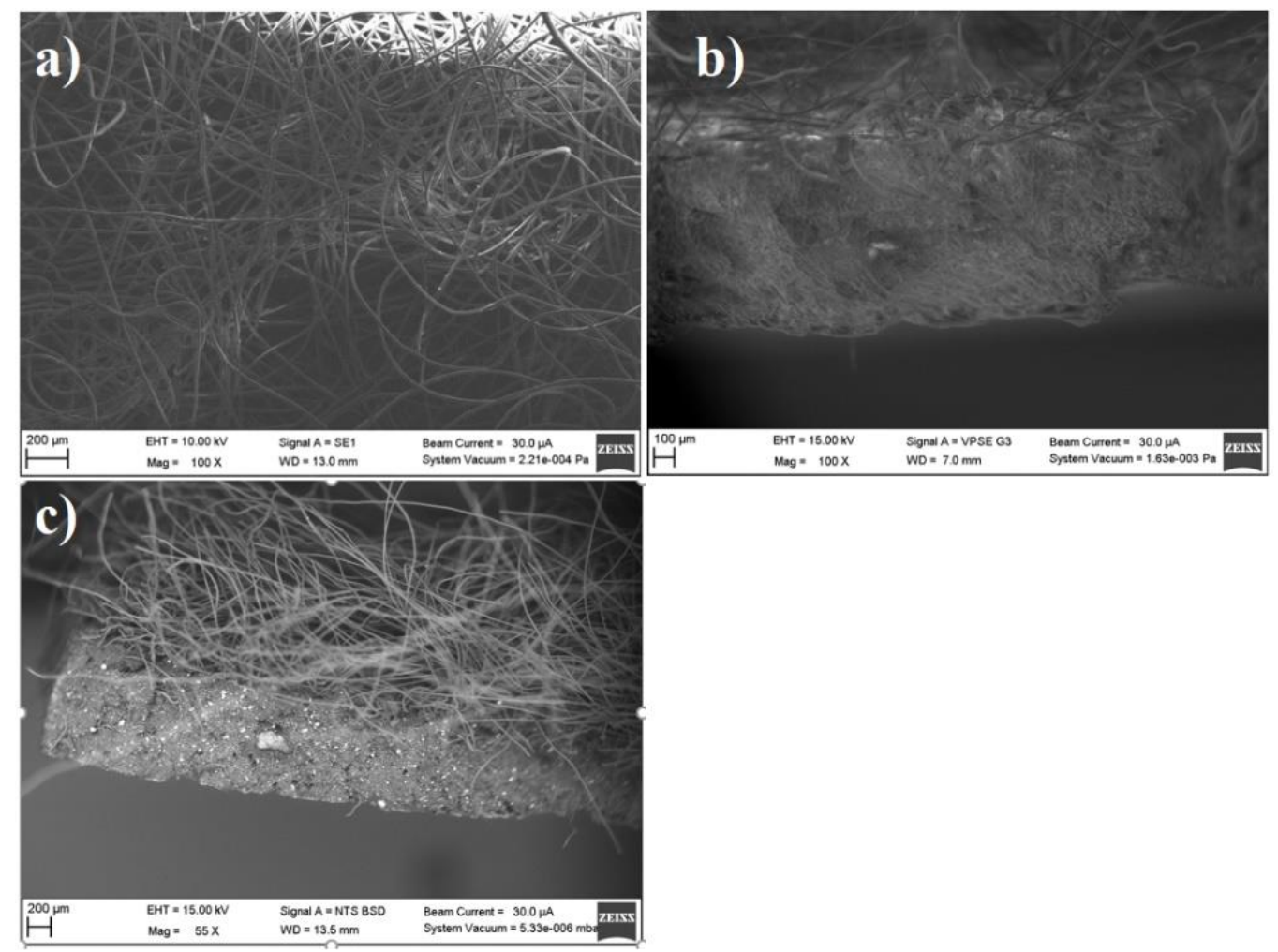

Fig. 2. SEM image (a) high vacuum, (b) low vacuum, secondary electrons, (c) low vacuum backscattered electrons

The use of backscattered (Fig. 2.c) electrons is obviously the most suitable method both for observing the morphology and detecting the differences in chemical composition. This technique was used to document the samples mounted in epoxy resin as well as fracture surfaces. 


\section{Results}

SEM observations discovered third phase of the composite - white particles (Fig. 3.). Chemical composition of the particles was analysed using energy-dispersive X-ray spectroscopy. The results might be inaccurate due to the low vacuum in the specimen chamber, however significant percentage of calcium (28.6 wt \%) was found. Based on the Xray analysis the white particles were identified as calcium carbonate which is frequently used as filler in polymer materials [9]. The SEM images are suitable for various methods of digital image analysis. Several measurements were performed such as determining the average fiber diameter $(20.27 \mu \mathrm{m})$, volume percentage of the filler $(15.1 \%)$, and maximum Feret diameter of the filler particles $(6.64 \mu \mathrm{m})$.

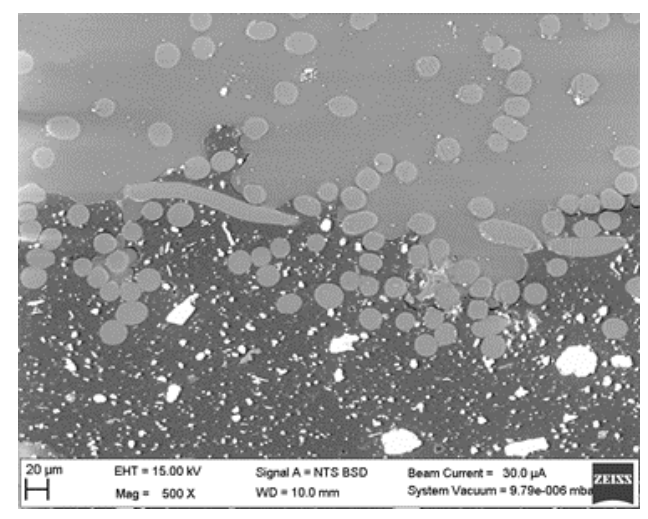

Fig. 3. SEM image, undeformed sample

The changes of deformation mechanism were studied on the deformed samples. At room temperature (Fig. 4.) the cracks initiated at the matrix-fiber interface and they propagated perpendicularly to the loading direction. When displayed in the dark field (Fig. 4.) the sample exhibits a change of optical properties which indicates the crack propagation.

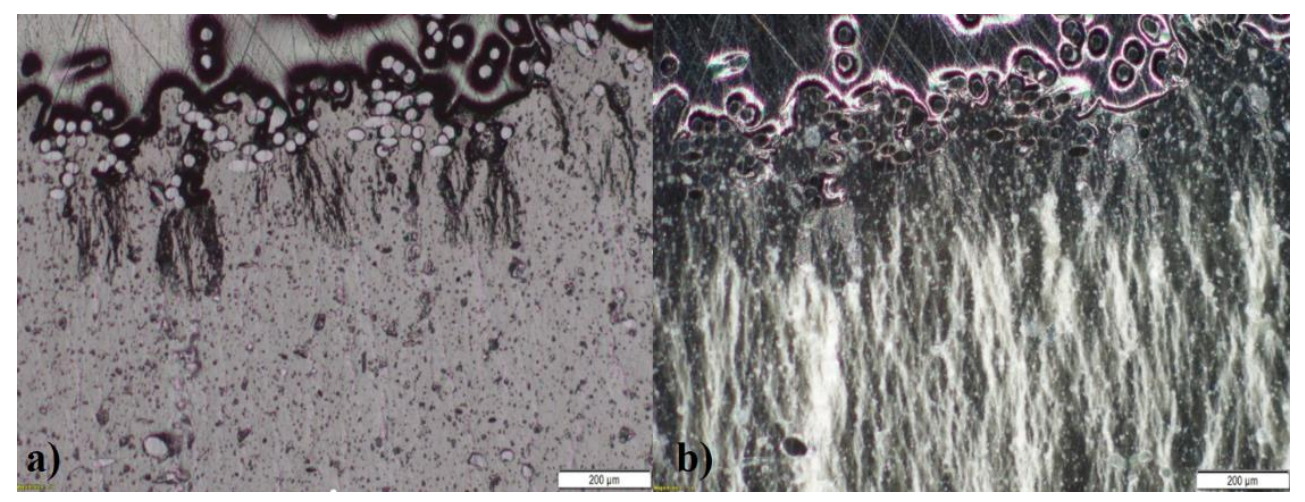

Fig. 4. Tensile specimen deformed at room temperature, (a) bright field, (b) dark field

Sample deformed at $140{ }^{\circ} \mathrm{C}$ (Fig. 5.) exhibits a different deformation behavior. The cracks propagated in the loading direction and they initiated at the matrix - filler particle interface.

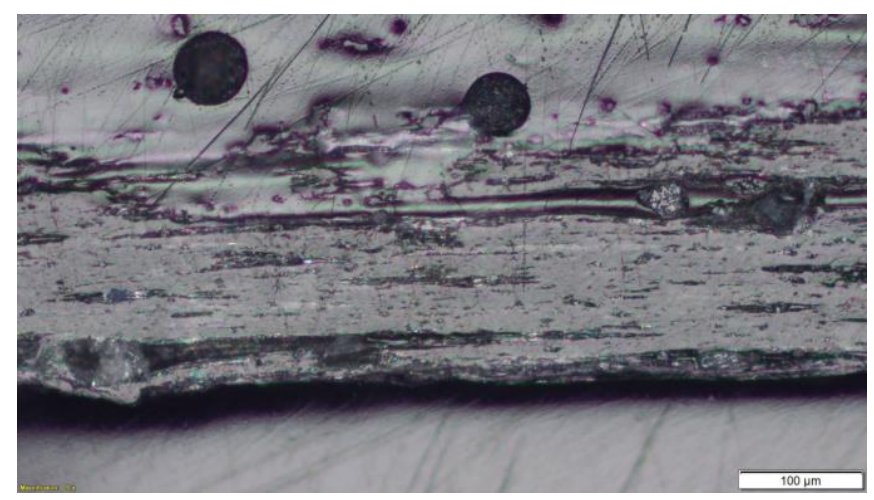

Fig. 5. Tensile specimen deformed at $140{ }^{\circ} \mathrm{C}$ 
The fractures exhibit noticeable changes as well. At room temperature (Fig. 6.a) the fracture propagated perpendicularly to the loading direction while at $60{ }^{\circ} \mathrm{C}$ (Fig. 6.b) it propagated at an angle. In addition, cavities appear close to the fracture surface of the $60{ }^{\circ} \mathrm{C}$ tensile specimen.

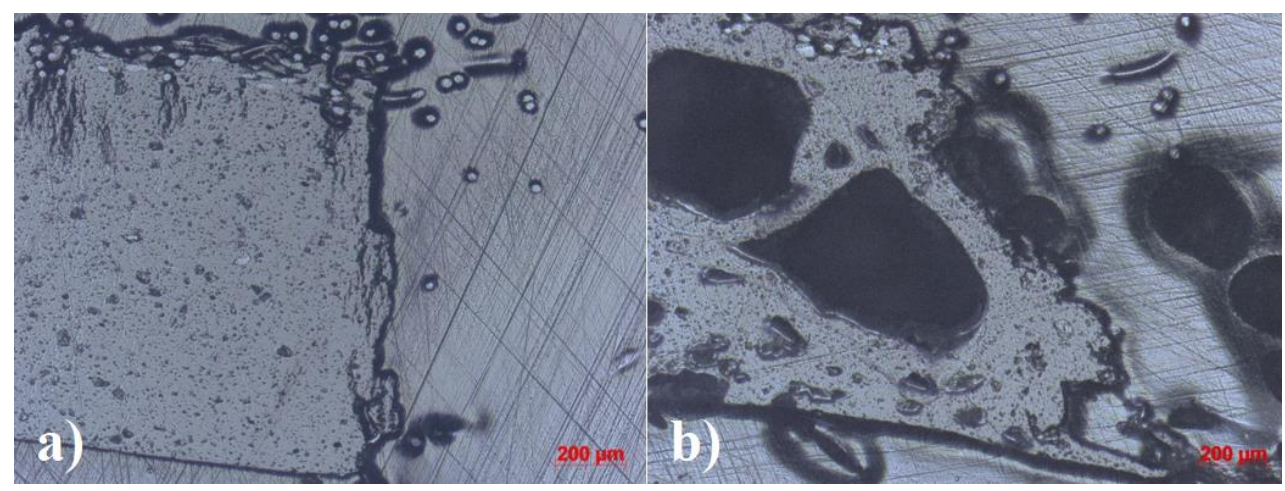

Fig. 6. Side view of fracture, (a) specimen tested at room temperature, (b) specimen tested at $60^{\circ} \mathrm{C}$

SEM imaging (Fig. 7) allow better comparison of the fracture surfaces. Flat fracture surface of the sample tested at $20^{\circ} \mathrm{C}$ (Fig. 7.a) indicates brittle behavior of the material at room temperature. At $60{ }^{\circ} \mathrm{C}$ (Fig. 7.b) the sample became very ductile, the surface exhibits no signs of brittle fracture and the cracking takes place in the longitudinal direction.

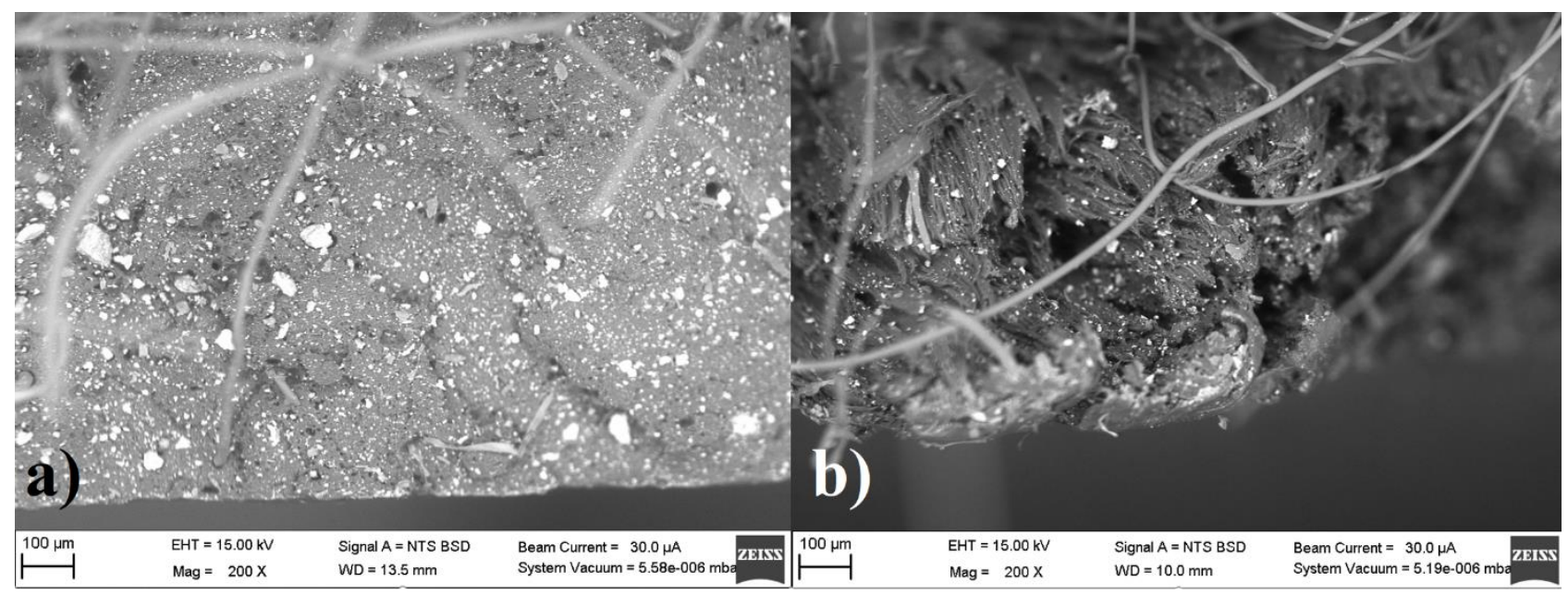

Fig. 7. SEM images of fracture surfaces, (a) specimen tested at room temperature, (b) specimen tested at $60{ }^{\circ} \mathrm{C}$

The samples observed through scanning electron microscope exhibit signs of damage caused by the electron beam (Fig. 8). This phenomenon has not been eliminated in the present study.

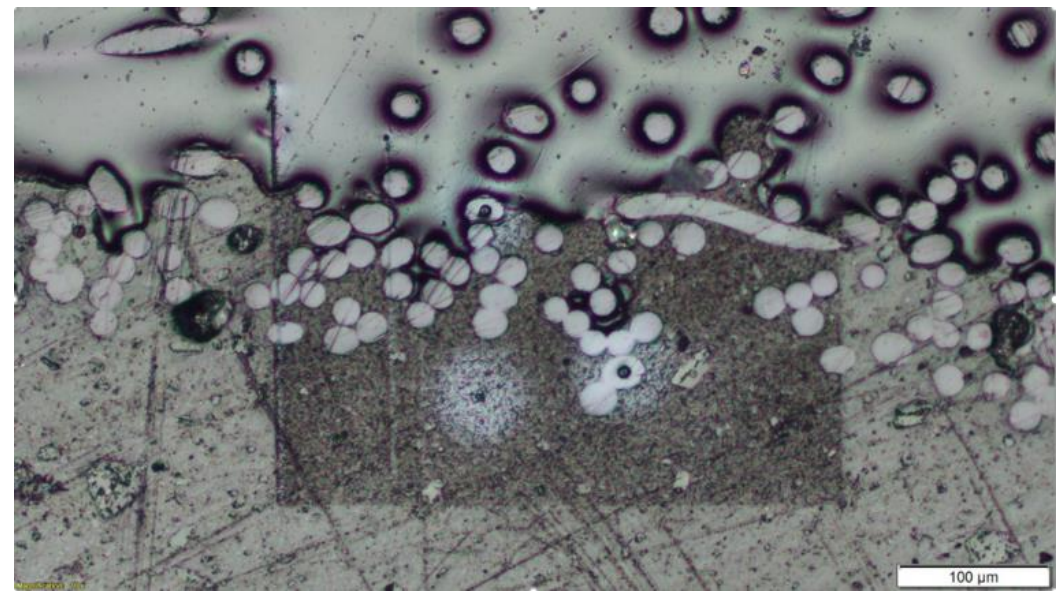

Fig. 8. Sample surface damaged by electron beam 


\section{Conclusion}

In this work a methodology for metallographic evaluation of polymer composites was proposed and subsequently tested on experimental material. The above described procedures have achieved satisfactory results in the image documentation of mounted samples and fracture surfaces. The acquired images were subjected to digital image analysis (phase percentage measurement, particle size measurement). In addition, temperature dependent changes in deformation mechanism of the tensile specimens were observed.

The results has shown that the metallographic methods are appplicable for polymer composite sample with some limitations. The epoxy was found to be the most suitable mounting resin due to its transparency and low viscosity. The best quality of imaging by scanning electron microscopy was achieved using backscattered electrons detector and low vacuum in the sample chamber. The low vacuum enviroment reduces the accuracy of any possible analytical technique (e.g. Energy-dispersive X-ray spectroscopy). Another disadvantage of above mentioned procedures is their connection to one specific material. The range of polymers used in composites is wide and of course the same procedure cannot be applicable for all of them. However the obtained results are acceptable and can be used in further research of moulding processes of this particular material (i.e. ethylene-propylene matrix with PET fibers).

As a starting point for further improvement, optimization of electron microscopic observation parameters is considered to reduce or prevent the damage to the sample by the electron beam.

\section{Acknowledgements}

The present contribution has been prepared under project LO1502 'Development of the Regional Technological Institute ' under the auspices of the National Sustainability Programme I of the Ministry of Education of the Czech Republic aimed to support research, experimental development and innovation.

\section{References}

[1] Jančář, Josef. (2003). Úvod do materiálového inženýrství polymerních kompozitů (Introdiction to material engineering of polymer composites). Vysoké učení technické v Brně, Fakulta chemická. ISBN: 80-214-2443-5, Brno.

[2] Ehrenstein, Gottfried W. (2006). Polymerní kompozitní materiály (Polymer composite materials). Scientia. ISBN 978-80-86960-29-6, Praha.

[3] Barbeo, Ever J. (2011). Introduction to composite materials design. Boca Raton : CRC Press.

[4] Hargitai, Hajnalka a Rácz, Ilona. (2012). Polymer composites, Volume 1: Macro- and microcomposites. WileyVCH. ISBN 978-3-527-32624-2, Weinheim.

[5] Janovec, Jiří, Cejpl, Jiří a Steidl, Josef. (2008). Perspektivní materiály (Promising materials). České vysoké učení technické v Praze, ISBN 978-80-01-04167-3, Praha.

[6] Kubatova, D[ana]; Melichar, M[artin] \& Pereira, A[lejandro] (2016). Tribological Testing of Polymeric Material, Proceedings of the 27th DAAAM International Symposium, pp.0428-0434, B. Katalinic (Ed.), Published by DAAAM International, ISBN 978-3-902734-08-2, ISSN 1726-9679, Vienna, Austria DOI:10.2507/27th.daaam.proceedings.063

[7] Zadražil, Martin. (2002). Zobrazování nevodivých praparátů metodou nenabíjecí elektronové mikroskopie (Imaging of non-conductive samples through charging electron microscopy). Vysoké učení technické v Brně. ISBN 80-214-2139-8, Brno.

[8] Kubínek, Roman, Šafářová, Klára a Vůjtek, Milan. (2011) Elektronová mikroskopie (Electron microscopy). Univerzita Palackého v Olomouci. ISBN 978-80-244-2739-3, Olomouc.

[9] www.welshcompositec.co.uk, (2011) Welsh Composites. Microscopy of Composites. Accessed on: 2018-04-03 